\title{
Partial CHARGE syndrome with bilateral retinochoroidal colobomas associated with 7q11.23 duplication syndrome: case report
}

\author{
Patrick L. Donabedian ${ }^{1}$, Jessica Y. Walia ${ }^{1}$ and Swati Agarwal-Sinha ${ }^{2^{*}}$ (D)
}

\begin{abstract}
Background: CHARGE syndrome is a relatively common cause of deafness and blindness resulting from failure to form the primordia of specific organs due to deficient contribution of neural crest cell derivatives. The majority of CHARGE syndrome cases are caused by heterozygous mutations in CHD7 on chromosome 8q21. Those with CHARGE syndrome without CHD7 mutation typically do not have an identified genetic defect. $7 q 11.23$ duplication syndrome is associated with mild facial dysmorphism, heart defects, language delay, and autism spectrum disorder. In the current literature, 7q11.23 duplication has not been associated with CHARGE syndrome, retinochoroidal colobomas, or significant ear abnormalities.
\end{abstract}

Case presentation: We describe a patient with 7q11.23 duplication syndrome and clinical CHARGE syndrome with no variant in CHARGE-associated genes.

Conclusions: This case highlights the still incomplete understanding of the pathogenesis of CHARGE syndrome and raises the possibility of a dose-sensitive effect of genes in the 7q11.23 critical region on neural crest differentiation and fate.

Keywords: CHARGE syndrome, 7q11.23 duplication, Coloboma, Case report

\section{Background}

Colobomas of the iris or choroid are rare malformations of the eye that occur when the embryonic optic fissure at either the anterior or posterior pole of the developing eye fails to close during the fifth week of embryogenesis. ${ }^{1-3}$ Small anterior or peripheral posterior colobomas may be asymptomatic. Large anterior colobomas are typically associated with photophobia, while large or central posterior colobomas lead to visual field defects, increased risk of retinal detachment, and impaired central acuity if the macula or nerve are involved. Severe coloboma phenotypes impair global eye development, leading to

*Correspondence: sxapublish@gmail.com

2 Department of Ophthalmology, Seattle Children's Hospital, University of Washington, Seattle, WA, USA

Full list of author information is available at the end of the article microphthalmia or anophthalmia. Both syndromic and isolated colobomas are genetically heterogeneous, and tracing the genes underlying these conditions has added much to our understanding of vertebrate eye development. The genetics of isolated and syndromic ocular coloboma are reviewed elsewhere [1].

CHARGE syndrome is characterized by a pattern of developmental anomalies. The CHARGE acronym stands for coloboma and cranial nerve defects, heart defects, atresia of the choanae, retardation of growth and mental development, genital underdevelopment, and ear abnormalities and sensorineural hearing loss. The criteria used to define CHARGE syndrome have been successively refined to be more specific [2-4]. CHARGE syndrome is typically sporadic, but may be familial and inherited in an autosomal dominant manner with high phenotypic variability, even between monozygotic twins [5]. The original author(s) and the source, provide a link to the Creative Commons licence, and indicate if changes were made. The images or other third party material in this article are included in the article's Creative Commons licence, unless indicated otherwise in a credit line to the material. If material is not included in the article's Creative Commons licence and your intended use is not permitted by statutory regulation or exceeds the permitted use, you will need to obtain permission directly from the copyright holder. To view a copy of this licence, visit http://creativecommons.org/licenses/by/4.0/. The Creative Commons Public Domain Dedication waiver (http://creativeco mmons.org/publicdomain/zero/1.0/) applies to the data made available in this article, unless otherwise stated in a credit line to the data. 
majority of cases are caused by heterozygous inactivating mutations in $\mathrm{CHD7}$, which codes for the transcription regulator chromodomain helicase DNA-binding protein 7 (CHD7) [6]. Failure of CHD7 to play its normal role in regulating genes relating to differentiation and motility of neural crest derivatives, including the neural crest component of the periocular mesenchyme, is the likely etiology of the abnormalities seen in CHARGE syndrome [7].

7q11.23 duplication syndrome is a rare genetic disorder associated with expressive and receptive language delay, mild facial dysmorphisms, hypotonia, heart defects, and cryptorchidism $[8,9]$. Comparison to the epidemiology of the reciprocal 7q11.23 deletion syndrome (WilliamsBeuren syndrome) indicate it likely goes frequently undiagnosed, and most cases have been identified by genetic testing of cohorts with autism spectrum disorder [10]. 7q11.23 duplication syndrome has never been reported to be associated with congenital anomalies of the globe, and has no known relationship to CHARGE syndrome.

We report a case of clinically atypical CHARGE syndrome associated with 7q11.23 duplication and with no identified CHD7 variant in a term baby girl born with small anterior and large posterior retinochoroidal colobomas, hemifacial palsy, atrial septal defect, and external ear abnormalities. We review the clinical features of the case and the results of genetic testing and their relationship to the known pathogenesis of CHARGE syndrome and $7 \mathrm{q} 11.23$ duplication.

\section{Case presentation}

A 4-day-old female, born at 38 weeks gestational age by spontaneous vaginal delivery, was transferred to our academic hospital for care in our neonatal intensive care unit and work-up for multiple facial malformations. She was born to a 23-year-old G1P0 female with maternal family history of Down syndrome and retinitis pigmentosa in, respectively, third- and fourthdegree relatives. On examination after delivery. she was noted to have left-sided anotia with postauricular tag and right-sided microtia (Fig. 1). Full ophthalmic exam at 5-days-old revealed bilateral iris colobomas and bilateral inferonasal retinochoroidal colobomas involving the optic disc and posterior pole, sparing the fovea (Figs. 2a and b). Other systemic findings included bilateral middle ear hypoplasia, atrial septal defect, small perimembranous ventricular septal defect, right hydronephrosis, and right-sided facial hemiparesis. Magnetic resonance imaging of the brain revealed posterior outpouchings of the globes consistent with posterior coloboma (Fig. 3). At 4 and 10 months of age, she was able to fix and follow with central, steady and maintained vision with both eyes. Mild hyperopia $(+2.00$ sphere) was noted on cycloplegic streak retinoscopy. At 15 months, she could walk, look for a hidden object, and stack blocks.

Given findings suggestive of CHARGE syndrome, genetic testing was performed with results summarized (Table 1). Microarray comparative genomic hybridization (SurePrint G3 Human CGH + SNP, Agilent Technologies) and supplemental fluorescence in situ hybridization discovered a duplication of $\sim 1.8 \mathrm{Mb}$ of $7 \mathrm{q} 11.23$ as well as homozygosity of $\sim 8.0 \mathrm{Mb}$ of $6 \mathrm{p} 21.3-22.2$. Whole exome sequencing of the patient and both parents (Invitae Whole Exome Boosted Trio, Invitae) discovered no variants in $C H D 7, S E M A 3 E$, or other genes related to the phenotype.

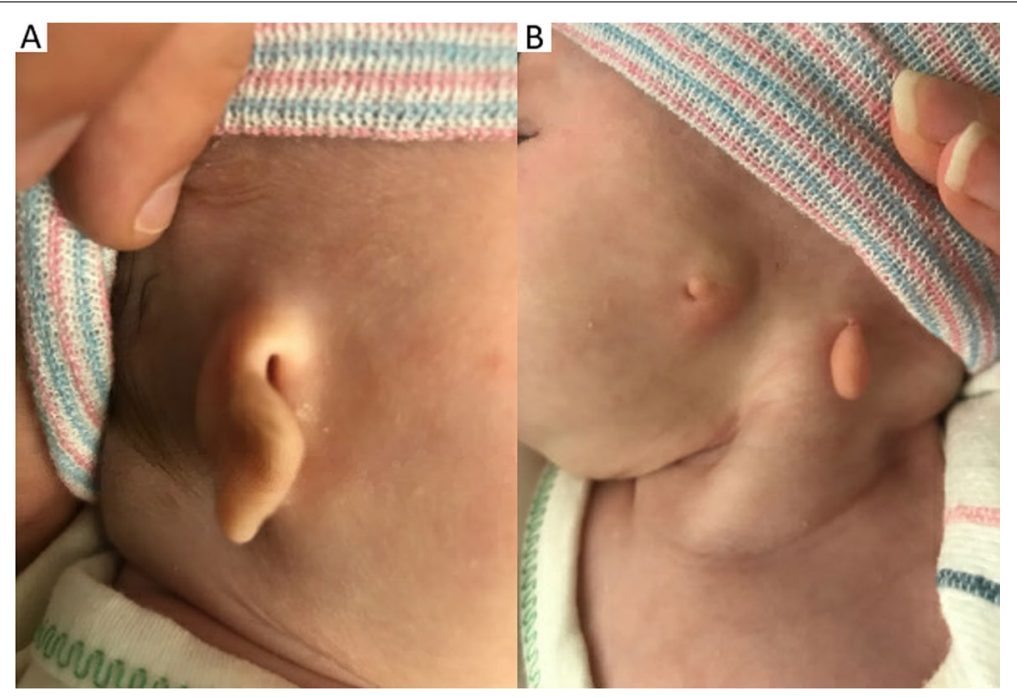

Fig. 1 External ears at birth; the left external ear is absent with a postauricular tag and the right ear is hypoplastic 


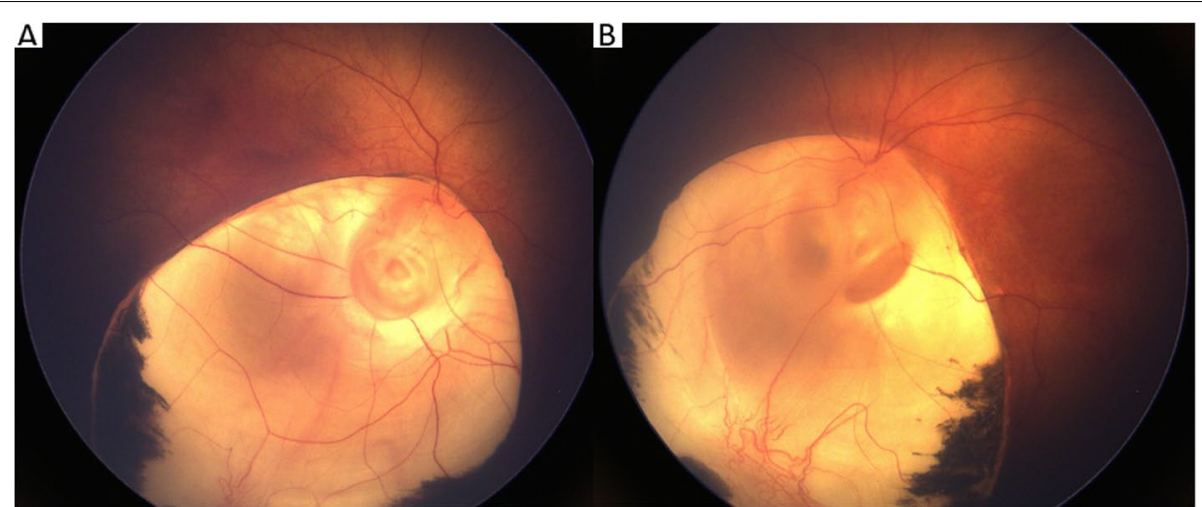

Fig. 2 a Eyes at 10 months of age; inferior colobomas of the iris in both eyes. b Fundus images taken on day of life 5. In both eyes, large inferonasal retinochoroidal colobomas involve the entire optic disc and partial macula

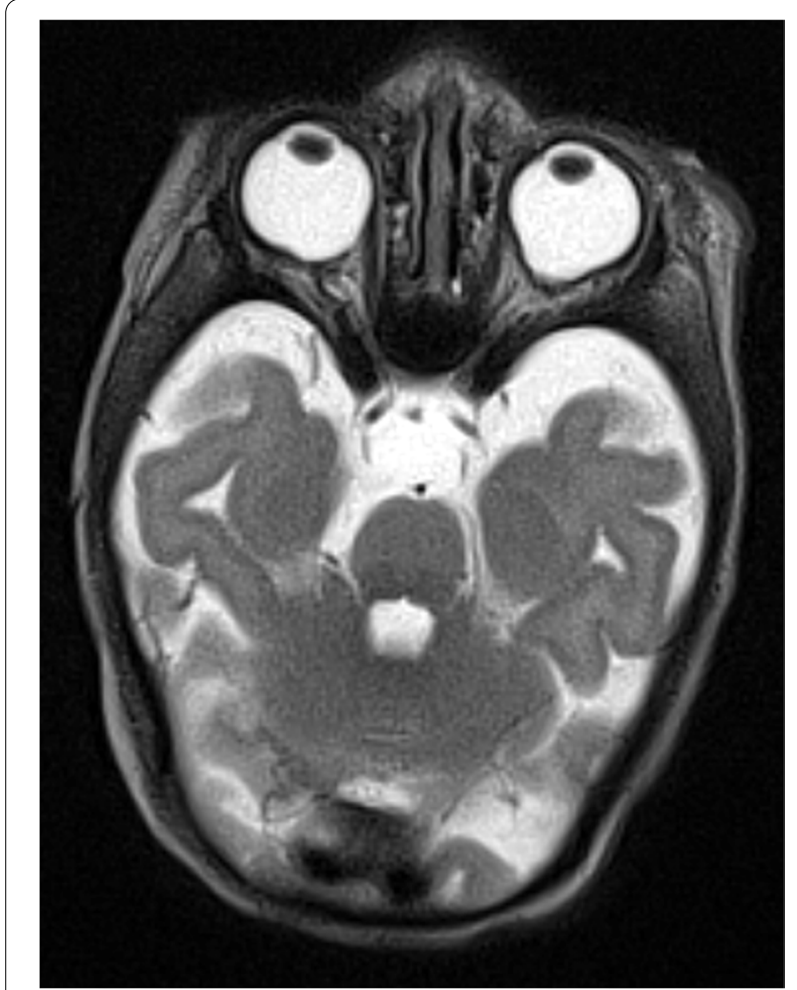

Fig. 3 T2-weighted MRI of the brain without contrast taken on day of life 14, showing bilateral outpouchings of the posterior contours of the globes consistent with posterior colobomas

\section{Discussion and conclusions}

How should we classify this patient's findings? Clinical criteria proposed for the diagnosis of CHARGE syndrome are summarized, along with the patient's characteristics, in Table 2. The original acronym was successively narrowed by Blake in 1998 and Verloes in 2005 to specify CHARGE syndrome and exclude other entities
[2, 3]. In 2016, after a decade of research on CHD7 mutations, Hale proposed widening the criteria to include patients with a partial clinical phenotype and a pathogenic CHD7 mutation [4]. Despite the widespread availability of genetic testing, CHARGE syndrome remains a clinical diagnosis [11]. In the absence of agreed-upon definitions, we describe this patient as having partial CHARGE syndrome because of the absence of two major criteria such as choanal atresia or cleft plate and pathologic $C H D 7$ variant.

A few years after CHARGE syndrome was first described, the pathogenesis of the syndrome was hypothesized to be due to abnormalities in the migration or maturation of neural crest cell derivatives [13]. In 2004, CHD7 was identified by sequence analysis of genes in the region of a novel $2.3 \mathrm{Mb}$ microdeletion in $8 \mathrm{q} 12$ in two individuals with CHARGE syndrome, and found to be mutated in most CHARGE cases and expressed in the implicated fetal tissues [14]. CHD7 mutations are detected in $50-90 \%$ of cases of CHARGE syndrome, depending on how stringent and which clinical criteria are used; clinical labs report significantly lower diagnostic yield (35\%) across all cases of suspected CHARGE syndrome, probably reflecting low, nonspecific thresholds for testing [15]. CHD7 is a chromatin regulator that interacts with other transcription factors to orchestrate transcription of genes essential for certain migratory neural crest $(\mathrm{NC})$ derivatives during embryogenesis [16, 17]. Failure of NC cells to migrate into the periocular mesenchyme is hypothesized to impair reciprocal signaling between ocular and periocular cell populations, leading to complete or partial arrest of optic fissure closure. The other variously present manifestations of CHARGE syndrome represent the failure of specific $\mathrm{NC}$ subpopulations to contribute to the formation of specific organ primordia. More than 800 pathogenic $C H D 7$ mutations 
Table 1 Results of genetic testing

\begin{tabular}{|c|c|c|}
\hline Test & Results & Interpretation \\
\hline \multirow[t]{2}{*}{$\begin{array}{l}\text { Microarray comparative genomic hybridization and fluorescence } \\
\text { in situ hybridization (aCGH \& FISH) }\end{array}$} & $\begin{array}{l}\text { Duplication of } 1818.7-1858.2 \mathrm{~kb} \text { of } \\
7 q 11.23 \text {, spanning maximum coordinates } \\
\text { of chr7:72,286,211-74,144,421 }\end{array}$ & $\begin{array}{l}\text { 7q11.23 (Williams-Beuren region) } \\
\text { duplication syndrome }\end{array}$ \\
\hline & $\begin{array}{l}\text { Homozygosity of } \sim 8.0 \mathrm{Mb} \text { of } 6 \mathrm{p} 21.3-22.2, \\
\text { spanning maximum coordinates of } \\
\text { chr } 6: 25,859,555-34,007,053\end{array}$ & Likely regions identical by descent \\
\hline \multirow{2}{*}{$\begin{array}{l}\text { Whole exome sequencing to mean depth of } 253 \times \text { and } 99.8 \% \text { cover- } \\
\text { age at } 20 x\end{array}$} & Copy number increases in chromosome 7q & Consistent with above \\
\hline & No variants identified & Normal \\
\hline
\end{tabular}

Table 2 Diagnostic criteria for CHARGE syndrome

\begin{tabular}{|c|c|c|c|c|}
\hline Pagon (1981) [12] & Blake (1998) [2] & Verloes (2005) [3] & Hale (2015) [4] & This Case Report \\
\hline \multirow[t]{2}{*}{$\begin{array}{l}\text { Coloboma } \\
\text { Heart malformations } \\
\text { Atresia of choanae } \\
\text { Retardation of mental } \\
\text { and somatic develop- } \\
\text { ment } \\
\text { Genital anomalies } \\
\text { Ear malformations }\end{array}$} & $\begin{array}{l}\text { Major criteria } \\
\text { Coloboma } \\
\text { Choanal atresia or cleft palate } \\
\text { Characteristic ear abnormali- } \\
\text { ties } \\
\text { Cranial nerve dysfunction }\end{array}$ & $\begin{array}{l}\text { Major criteria } \\
\text { Coloboma } \\
\text { Choanal atresia } \\
\text { Hypoplastic semicircular } \\
\text { canals }\end{array}$ & $\begin{array}{l}\text { Major criteria } \\
\text { Coloboma } \\
\text { Choanal atresia or cleft } \\
\text { palate } \\
\text { Abnormal external, middle or } \\
\text { inner ears } \\
\text { Pathogenic CHD7 variant }\end{array}$ & $\begin{array}{l}\text { Major criteria } \\
\text { Coloboma } \\
\text { Middle and external ear } \\
\text { hypoplasia }\end{array}$ \\
\hline & $\begin{array}{l}\text { Minor criteria } \\
\text { Genital hypoplasia } \\
\text { Developmental delay } \\
\text { Heart or aortic arch malfor- } \\
\text { mations } \\
\text { Growth hormone deficiency } \\
\text { Orofacial cleft } \\
\text { Tracheoesophageal fistula } \\
\text { Characteristic face }\end{array}$ & $\begin{array}{l}\text { Minor criteria } \\
\text { Heart or esophagus malfor- } \\
\text { mation } \\
\text { External or middle ear } \\
\text { abnormality } \\
\text { Rhombencephalic dysfunc- } \\
\text { tion, including sensorineural } \\
\text { hearing loss } \\
\text { Hypothalamoo-hypophyseal } \\
\text { dysfunction (gonadotropin or } \\
\text { growth hormone deficiency) } \\
\text { Intellectual disability }\end{array}$ & $\begin{array}{l}\text { Minor criteria } \\
\text { Cranial nerve dysfunction } \\
\text { Dysphagia or feeding dif- } \\
\text { ficulty } \\
\text { Structural brain abnormali- } \\
\text { ties } \\
\text { Developmental delay, intel- } \\
\text { lectual disability, or autism }\end{array}$ & $\begin{array}{l}\text { Minor criteria } \\
\text { Facial hemipalsy, feeding and } \\
\text { swallowing difficulty } \\
\text { Atrial septal defect and small } \\
\text { perimembranous ventricular } \\
\text { septal defect }\end{array}$ \\
\hline $\begin{array}{l}\text { Inclusion rule } \\
4 \text { criteria present }\end{array}$ & $\begin{array}{l}\text { Inclusion rule } \\
4 \text { major OR } 3 \text { major }+3 \\
\text { minor }\end{array}$ & $\begin{array}{l}\text { Inclusion rule } \\
\text { Typical CHARGE: } 3 \text { major OR } \\
2 \text { major }+2 \text { minor } \\
\text { Partial CHARGE: } 2 \text { major }+1 \\
\text { minor } \\
\text { Atypical CHARGE: } 2 \text { major }+0 \\
\text { minor OR } 1 \text { major }+3 \text { minor }\end{array}$ & $\begin{array}{l}\text { Inclusion rule } \\
2 \text { major }+ \text { any number of } \\
\text { minor }\end{array}$ & \\
\hline
\end{tabular}

have been identified [6, 18], primarily nonsense or frameshift mutations distributed randomly throughout coding regions, as well as some splice site mutations. CHARGE syndrome has also been linked to the SEMA3E gene in $7 q 21.11$, once by de novo mutation and once by a novel balanced translocation of chromosomes 2 and $7[19,20]$. SEMA3E codes for a class 3 semaphorin that guides axonal and vascular growth during mouse embryogenesis [21] and is required for migration of cranial neural crest in zebrafish [22]. Pathogenic CHD7 and $S E M A 3 E$ mutations have also been discovered in cases of Kallmann syndrome (KS) and normosmic hypogonadotropic hypogonadism $(\mathrm{nHH})$, suggesting that some cases of $\mathrm{KS} / \mathrm{nHH}$ represent a mild CHARGE phenotype where only specialized axonal growth is affected $[23,24]$.
These investigations link CHARGE syndrome at a genetic or embryologic level to a variety of other syndromes of maldevelopment, including Sox2 anophthalmia, Alagille, Pallister-Hall and Feingold syndromes, and 22q11.2 deletion (DiGeorge) syndrome.

Other causes for CHARGE syndrome have been proposed, sometimes to explain the many cases without an identifiable genetic variant, as well as the variability in phenotype.

CHARGE syndrome has been reported in a child with a de novo inverted duplication [15] (q22q24.3) [25], in a 6.5 Mb duplication of 2p25 [26], in duplication $8 \mathrm{q}$ and deletion $4 \mathrm{q}$ from paternal unbalanced translocation $\mathrm{t}(4 ; 8)$ (q34;q22.1) [27], in de novo balanced $t(6 ; 8)(6 p 8 p ; 6 q 8 q)$ [28]; some of these cases predate the availability of 
clinical sequencing and cannot exclude a co-occuring $C D H 7$ mutation. De novo mutations of $C H D 7$ have been found to occur primarily in the paternal germline, suggesting that imprinting may be involved [29]. CHD7 preferentially localizes to chromatin sites with histone $\mathrm{H} 3$, lysine 4 methylation, suggesting that heritable methylation patterns may influence the CHARGE phenotype. Both excess and deficiency of vitamin A have been linked to the anomalies seen in CHARGE syndrome [30, 31]; CHD7 and retinoic acid signaling appear to interact in both inner ear and olfactory bulb development [32, 33].

The clinical features and putative genetic causes of 7q11.23 duplication syndrome bear little relationship to those of CHARGE syndrome, with a distinctive cognitive-behavioral profile (severe language delay with sparing of visuospatial ability, autism spectrum disorder), mild, nonspecific facial dysmorphism and cardiac defects, hypotonia, and normal growth [10]. Single congenital anomalies may be present but are apparently random, and coloboma has not been reported [34]. 7q11.23 duplication syndrome is diagnosed at a much lower rate than the reciprocal 7q11.23 deletion (Williams syndrome), even though from a molecular perspective they should be roughly equal in incidence [35]; a fact attributed to the generally mild and nonspecific phenotype, though a contribution from embryonic lethality cannot be excluded. The roughly 28 genes in the critical region have been studied fairly extensively and include genes with roles in embryonic development, connective tissue, cytoskeleton formation, glucose metabolism, chromatin remodeling, and synapse formation as well as several genes with unknown function [10]. Genotype-phenotype correlations are mostly well-established only in the deletion syndrome; excess dosage of gene products in 7q11.23 duplication syndrome is hypothesized to subtly impair development, primarily of the brain. Symmetrical DNA methylation changes have been observed in patients with 7q11.23 duplication and deletion, suggesting that the function of many genes outside of the critical region may be affected [36].

Many hypotheses would explain the findings in our patient. Coverage of flanking intronic regions by exome sequencing makes a splice site mutation unlikely, but an intronic point mutation or insertion/deletion could introduce a non-canonical splice site or impair splicing regulatory elements, contributing to CHD7 (or SEMA3E) haploinsufficiency [37]. Somatic mosaicism for CHD7 variants has been reported in CHARGE syndrome and would have gone undetected if present at a low level in peripheral blood. An interacting environmental factor is already likely to contribute to most cases of CHARGE syndrome, given drastic differences in clinical findings even between monozygotic twins. Her 1.8 Mb duplication was at the upper end of the typical range seen in 7q11.23 duplication syndrome, but would not involve any novel genes in the breakpoints. The global hypomethylation associated with 7q11.23 duplication may have altered CHD7's ability to bind to the appropriate chromatin regions. The 7q11.23 duplication may be entirely unrelated to the CHARGE phenotype-a case of "true, true and unrelated." Overall, this patient's presentation, and the variability in CHARGE syndrome, indicates that a seemingly monogenic disorder actually involves multiple insults that interact to produce very different phenotypes, a model that has been proposed for idiopathic hypogonadotropic hypogonadism [38].

Visual prognosis in retinochoroidal colobomas is highly variable. Lack of involvement of the fovea [39, 40], absence of cysts and a structurally normal globe and cornea [41] predict good visual acuity later in life. In our patient, coloboma appears to involve the inferonasal macula but spare the fovea, an encouraging sign. Early correction of refractive error and anisometropia and therapy for amblyopia is as important as in any other child. Additionally, likely due to structural abnormalities within the coloboma or at the margins of normal retina [42, 43], rhegmatogenous retinal detachments are highly prevalent in colobomatous eyes, affecting $4-40 \%$ of cases [44-46]. Regular fundoscopic exam is recommended to detect these vision-threatening complications early. Retrospective studies $[45,47]$ suggest that prophylactic laser photocoagulation may reduce the risk of retinal detachment and conserve long-term visual acuity in eyes affected by retinochoroidal coloboma, but evidence to guide patient selection and timing is scarce. CHARGE patients in general benefit from a multidisciplinary approach, given their variable developmental delays and sometimes profound deficiencies in sight, hearing and smell $[48,49]$. Our patient, currently 17 months old, is doing well at home with her parents and is followed in ophthalmology, otolaryngology, cardiology and pulmonology clinics. She has a bone-anchored hearing aid and can say several words. Her parents are aware of her guarded visual prognosis, despite her currently preserved visual acuity, and are in touch with the Florida School for the Blind.

We report a case of CHARGE syndrome associated with 7q11.23 duplication in a baby girl with small iris colobomas, large posterior retinochoroidal colobomas involving the disk and macula, hemifacial palsy, atrial septal defect, and external ear malformations. Whole exome sequencing revealed no variant in $C H D 7$, $S E M A 3 E$, or any other gene related to the phenotype. While failure to detect pathogenic variants is not uncommon in CHARGE syndrome, reflecting our incomplete understanding, cytogenetic abnormalities are unusual. 
This case adds to the still-incomplete story of the genetics of CHARGE syndrome and raises the possibility of a role for dosage-sensitive genes in the 7q11.23 critical region in NC specification and fate during embryogenesis.

\section{Abbreviations}

CHARGE: Coloboma, heart defects, atresia of the choanae, retardation of mental and somatic development, genital abnormalities, and ear and hearing problems; NC: Neural crest; KS: Kallmann syndrome; $\mathrm{nHH}$ : Normosmic hypogonadotropic hypogonadism.

\section{Acknowledgements}

The authors would like to thank the patient and her parents.

\section{Authors' contributions}

PLD, contributed to literature search, case reporting, tables, writing and revising the manuscript. JFY, contributed to literature search, case reporting, and revising the manuscript. SAS, contributed to study design, data collection, editing and final approval of the manuscript. All authors have read and approved the manuscript.

\section{Funding}

Not applicable.

\section{Availability of data and materials}

"The data that support the findings of this study are not publicly available due to their containing information that could compromise the privacy of patient but are available from the corresponding author (SAS) upon reasonable request".

\section{Declarations}

\section{Ethics approval and consent to participate}

Written informed consent to participate was obtained from the patient's parents.

\section{Consent for publication}

Written informed consent for publication of clinical details and images was obtained from the parents of the patient. A copy of the consent form is available for review by the Editor of this journal.

\section{Competing interests}

The authors declare they have no competing interests.

\section{Author details}

'Department of Ophthalmology, University of Florida College of Medicine, Gainesville, FL, USA. ²Department of Ophthalmology, Seattle Children's Hospital, University of Washington, Seattle, WA, USA.

Received: 25 May 2021 Accepted: 3 February 2022

Published online: 04 March 2022

\section{References}

1. ALSomiry AS, Gregory-Evans CY, Gregory-Evans K. An update on the genetics of ocular coloboma. Hum Genet. 2019;138(8 9):865-80.

2. Blake KD, Davenport SLH, Hall BD, Hefner MA, Pagon RA, Williams MS, et al. CHARGE Association: An Update and Review for the Primary Pediatrician. Clin Pediatr (Phila). 1998;37(3):159-73.

3. Verloes A. Updated diagnostic criteria for CHARGE syndrome: A proposal. Am J Med Genet Part A. 2005;133A(3):306-8. https://doi.org/10.1002/ ajmg.a.30559.

4. Hale CL, Niederriter AN, Green GE, Martin DM. Atypical phenotypes associated with pathogenic CHD7 variants and a proposal for broadening CHARGE syndrome clinical diagnostic criteria. Am J Med Genet Part A. 2016:170(2):344-54. https://doi.org/10.1002/ajmg.a.37435.
5. Jongmans MCJ, Admiraal RJ, van der Donk KP, Vissers LELM, Baas AF, Kapusta L, et al. CHARGE syndrome: the phenotypic spectrum of mutations in the CHD7 gene. J Med Genet. 2006;43(4):306-14.

6. Janssen N, Bergman JEH, Swertz MA, Tranebjaerg L, Lodahl M, Schoots J, et al. Mutation update on the CHD7 gene involved in CHARGE syndrome. Hum Mutat. 2012;33(8):1149-60. https://doi.org/10.1002/ humu.22086 Available from.

7. Gage PJ, Rhoades W, Prucka SK, Hjalt T. Fate Maps of Neural Crest and Mesoderm in the Mammalian Eye. Investig Opthalmology Vis Sci. 2005;46(11):4200. Available from: https://doi.org/10.1167/iovs.05-0691.

8. Mervis CB, Morris CA, Klein-Tasman BP, Velleman SL, Osborne LR. 7q11.23 Duplication Syndrome. 2015 Nov 25 [updated 2021 Mar 25]. In: Adam MP, Ardinger HH, Pagon RA, Wallace SE, Bean LJH, Gripp KW Mirzaa GM, Amemiya A, editors. GeneReviews ${ }^{\circledR}$ [Internet]. Seattle: University of Washington; 1993-2022.

9. Morris CA, Mervis CB, Paciorkowski AP, Abdul-Rahman O, Dugan SL, Rope AF, et al. 7q11.23 Duplication syndrome: Physical characteristics and natural history. Am J Med Genet Part A. 2015;167(12):2916-35. https://doi.org/10.1002/ajmg.a.37340.

10. Merla G, Brunetti-Pierri N, Micale L, Fusco C. Copy number variants at Williams-Beuren syndrome 7q11.23 region. Hum Genet. 2010;128(1):3-26.

11. Bergman JEH, Janssen N, Hoefsloot LH, Jongmans MCJ, Hofstra RMW, van Ravenswaaij-Arts CMA. CHD7 mutations and CHARGE syndrome: the clinical implications of an expanding phenotype. J Med Genet. 2011;48(5):334-42.

12. Pagon RA, Graham JM Jr, Zonana J, Yong SL. Coloboma, congenital heart disease, and choanal atresia with multiple anomalies: CHARGE association. J Pediatr. 1981;99(2):223-7. https://doi.org/10.1016/s00223476(81)80454-4

13. Siebert JR, Graham JM, MacDonald C. Pathologic features of the CHARGE association: Support for involvement of the neural crest. Teratology. 1985;31(3):331-6. https://doi.org/10.1002/tera.1420310303.

14. Vissers LELM, van Ravenswaaij CMA, Admiraal R, Hurst JA, de Vries BBA, Janssen IM, et al. Mutations in a new member of the chromodomain gene family cause CHARGE syndrome. Nat Genet. 2004;36(9):955-7.

15. Bartels CF, Scacheri C, White L, Scacheri PC, Bale S. Mutations in the CHD7 Gene: The Experience of a Commercial Laboratory. Genet Test Mol Biomarkers. 2010;14(6):881-91.

16. Gage PJ, Hurd EA, Martin DM. Mouse Models for the Dissection of CHD7 Functions in Eye Development and the Molecular Basis for Ocular Defects in CHARGE Syndrome. Investig Opthalmology Vis Sci. 2015;56(13):7923.

17. Schulz Y, Wehner P, Opitz L, Salinas-Riester G, Bongers EMHF, van Ravenswaaij-Arts CMA, et al. CHD7, the gene mutated in CHARGE syndrome, regulates genes involved in neural crest cell guidance. Hum Genet. 2014;133(8):997-1009.

18. CHD7 Database [Internet]. [cited 2021 Mar 9]. Available from: https:// chd7.org

19. Martin DM, Sheldon S, Gorski JL. CHARGE association with choanal atresia and inner ear hypoplasia in a child with a de novo chromosome translocation t(2;7)(p14;q21.11). Am J Med Genet. 2001;99(2):115-9.

20. Lalani SR. SEMA3E mutation in a patient with CHARGE syndrome. J Med Genet. 2004:41(7):e94-e94.

21. Oh W-J, Gu C. The role and mechanism-of-action of Sema3E and Plexin-D1 in vascular and neural development. Semin Cell Dev Biol. 2013;24(3):156-62.

22. Liu Z, Guo J, Lu Y, Liu W, Fu X, Yao T, et al. Sema3E is required for migration of cranial neural crest cells in zebrafish: Implications for the pathogenesis of CHARGE syndrome. Int J Exp Pathol. 2019;100(4):234-43.

23. Cariboni A, André V, Chauvet S, Cassatella D, Davidson K, Caramello A, et al. Dysfunctional SEMA3E signaling underlies gonadotropin-releasing hormone neuron deficiency in Kallmann syndrome. J Clin Invest. 2015;125(6):2413-28

24. Marcos S, Sarfati J, Leroy C, Fouveaut C, Parent P, Metz C, et al. The Prevalence of CHD7 Missense Versus Truncating Mutations Is Higher in Patients With Kallmann Syndrome Than in Typical CHARGE Patients. J Clin Endocrinol Metab. 2014;99(10):E2138-43.

25. North KN, Wu BL, Cao BN, Whiteman DAH, Korf BR. CHARGE association in a child with de novo inverted duplication (14)(q22 $\rightarrow$ q24.3). Am J Med Genet. 1995;57(4):610-4. https://doi.org/10.1002/ajmg.1320570419 Available from. 
26. Sperry ED, Schuette JL, van Ravenswaaij-Arts CMA, Green GE, Martin DM. Duplication 2p25 in a child with clinical features of CHARGE syndrome. Am J Med Genet Part A. 2016;170(5):1 148-54. https://doi.org/10.1002/ ajmg.a.37592.

27. Khalifa OA, Walter CU, Rahbeeni ZA, Verloes A. Terminal $4 q$ deletion and 8q duplication in a patient with CHARGE-like features. Eur J Med Genet. 2011;54(2):173-6.

28. Hurst JA, Meinecke P, Baraitser M. Balanced t(6;8)(6p8p;6q8q) and the CHARGE association. J Med Genet. 1991;28(1):54-5.

29. Pauli S, von Velsen N, Burfeind P, Steckel M, Mänz J, Buchholz A, et al. CHD7 mutations causing CHARGE syndrome are predominantly of paternal origin. Clin Genet. 2012;81(3):234-9. https://doi.org/10.1111/j. 1399-0004.2011.01701.x.

30. WILSON JG, ROTH CB, WARKANY J. An analysis of the syndrome of malformations induced by maternal vitamin A deficiency. Effects of restoration of vitamin A at various times during gestation. Am J Anat. 1953;92(2):189-217.

31. Lupo G, Gestri G, O'Brien M, Denton RM, Chandraratna RAS, Ley SV, et al. Retinoic acid receptor signaling regulates choroid fissure closure through independent mechanisms in the ventral optic cup and periocular mesenchyme. Proc Natl Acad Sci. 2011;108(21):8698-703.

32. Micucci JA, Layman WS, Hurd EA, Sperry ED, Frank SF, Durham MA, et al. $\mathrm{CHD7}$ and retinoic acid signaling cooperate to regulate neural stem cell and inner ear development in mouse models of CHARGE syndrome. Hum Mol Genet. 2014;23(2):434-48.

33. Yao H, Hill SF, Skidmore JM, Sperry ED, Swiderski DL, Sanchez GJ, et al. CHD7 represses the retinoic acid synthesis enzyme ALDH1A3 during inner ear development. JCl Insight. 2018;3(4)

34. Van der Aa N, Rooms L, Vandeweyer G, van den Ende J, Reyniers E, Fichera $\mathrm{M}$, et al. Fourteen new cases contribute to the characterization of the 7q11.23 microduplication syndrome. Eur J Med Genet. 2009;52(2 3):94-100.

35. Somerville MJ, Mervis CB, Young EJ, Seo E-J, del Campo M, Bamforth S, et al. Severe Expressive-Language Delay Related to Duplication of the Williams-Beuren Locus. N Engl J Med. 2005;353(16):1694-701.

36. Strong E, Butcher DT, Singhania R, Mervis CB, Morris CA, De Carvalho $D$, et al. Symmetrical Dose-Dependent DNA-Methylation Profiles in Children with Deletion or Duplication of 7q11.23. Am J Hum Genet. 2015;97(2):216-27.

37. Vaz-Drago R, Custódio N, Carmo-Fonseca M. Deep intronic mutations and human disease. Hum Genet. 2017;136(9):1093-111.

38. Pitteloud N, Quinton R, Pearce S, Raivio T, Acierno J, Dwyer A, et al. Digenic mutations account for variable phenotypes in idiopathic hypogonadotropic hypogonadism. J Clin Invest. 2007;117(2):457-63.

39. Olsen TW, Summers CG, Knobloch WH. Predicting visual acuity in children with colobomas involving the optic nerve. J Pediatr Ophthalmol Strabismus. 1996;33(1):47-51.

40. Olsen TW. Visual acuity in children with colobomatous defects. Curr Opin Ophthalmol. 1997;8(3):63-7.

41. Hornby SJ, Adolph S, Gilbert CE, Dandona L, Foster A. Visual acuity in children with coloboma: clinical features and a new phenotypic classification system. Ophthalmology. 2000;107(3):511-20.

42. Gopal L, Khan B, Jain S, Prakash VS. A Clinical and Optical Coherence Tomography Study of the Margins of Choroidal Colobomas. Ophthalmology. 2007;114(3):571-80.

43. Gopal L, Badrinath SS, Sharma T, Parikh SN, Biswas J. Pattern of Retinal Breaks and Retinal Detachments in Eyes with Choroidal Coloboma. Ophthalmology. 1995;102(8):1212-7.

44. Daufenbach DR, Ruttum MS, Pulido JS, Keech RV. Chorioretinal colobomas in a pediatric population. Ophthalmology. 1998;105(8):1455-8.

45. Uhumwangho OM, Jalali S. Chorioretinal coloboma in a paediatric population. Eye. 2014;28(6):728-33.

46. Hussain R, Abbey A, Shah A, Drenser K, Trese M, Capone A. Chorioretinal coloboma complications: retinal detachment and choroidal neovascular membrane. J Ophthalmic Vis Res. 2017;12(1):3.

47. Tripathy K, Chawla R, Sharma YR, Venkatesh P, Sagar P, Vohra R, et al. Prophylactic laser photocoagulation of fundal coloboma: does it really help? Acta Ophthalmol. 2016;94(8):e809-10. https://doi.org/10.1111/aos.12975.

48. Goldson E, Smith AC, Stewart JM. The CHARGE association How well can they do? Am J Dis Child. 1986;140(9):918-21.
49. Brown D. CHARGE syndrome "behaviors": challenges or adaptations? Am J Med Genet A. 2005;133A(3):268-72. https://doi.org/10.1002/ajmg.a. 30547.

\section{Publisher's Note}

Springer Nature remains neutral with regard to jurisdictional claims in published maps and institutional affiliations.
Ready to submit your research? Choose BMC and benefit from:

- fast, convenient online submission

- thorough peer review by experienced researchers in your field

- rapid publication on acceptance

- support for research data, including large and complex data types

- gold Open Access which fosters wider collaboration and increased citations

- maximum visibility for your research: over 100M website views per year

At BMC, research is always in progress.

Learn more biomedcentral.com/submissions 